\title{
Evaluation competency-based in Internship: especial reference to evaluation rubric and final reports
}

\author{
M. Moltó-Aribau*, A. Tena-Torruella* and A. Vendrell* \\ * Departament of Bussines Administration. University of Lleida
}

\begin{abstract}
A working group of lecturers of University of Lleida (UdL), involved as academic tutors in Internship, propose to adapt the traditional model of evaluation of Internship to a new competencybased model as proposes The European Higher Education Space (EEES, its acronym in Spanish). This implies to redefine the evaluation process, introducing objective elements and guaranteeing the integral performance assessment of the students, according both academic and professional profile. The proposal includes the definition of: evaluation process, evaluator agents, competences to evaluate, indicators/evidence of every competency and finally scales and levels of achievements. As a result, we built a rubric of evaluation which includes: competences, indicators, scales, agents and moments of evaluation that can be applied in different degrees of UdL. Moreover we define a final evaluation report which contains learning outcomes and shows findings, conclusions, and recommendations that can be used to guide student's improvement and decision making about them. This proposal was partially implemented in the degrees of Industrial Engineering, Computer Engineering and Business Administration with very positive students' acceptation but we need more experience and to refine our model, making it simpler and more usable if we want to generalize it to other higher education institution.
\end{abstract}

Keywords: competence-based evaluation; rubric; final evaluation report; learning outcomes

\section{Introduction}

Our team is formed by lecturers and part time professors from two centres of UdL and has being working as academic tutors o coordinators in Internship at UdL for a very long time. Internship are supervised practice in companies and offers students a period of practical experience in the industry relating to their field of study. Students spent in the companies four months part-time or two months full-time. This experience is valuable to students as a means of allowing them to experience how their studies are applied in the "real world". Internship courses are compulsory in all UdL's degrees.

Most of the members of the group are lecturers of UdL da and all of us were involved in Internship as academic tutors or members of the staff of our faculties: Polytechnic School and Faculty of Economy and Law of University of Lleida. Our team is interdisciplinary and our proposal tries to be general and applicable to several UdL's degrees and also to other higher education institutions.

In concordance with the necessary review promoted by European Higher Education Space (EEES, its acronym in Spanish) we start working on the incorporation of the competency-based evaluation in Internship as a way to verify the assessment of our students. As a result we defined an integral competency-based evaluation process for Internship, applicable in the same field in other higher education institutions, with few adaptations.

We also define a final evaluation report that shows learnings outcomes of every student. This is the innovative contribution of our work because the use of rubrics is generalized in a huge range of higher educational institutions but not the elaboration 
of a personalized report where students can have detailed the qualification of every competency evaluated.

\section{Methodology}

The methodology used to build the integral competency-based evaluation of the Internship has being developed following the next process. First of all we design the rubric, detailing the definition of competences and determining evidences of every competency (phase 1). A rubric is an evaluation tool or set of guidelines used to promote the consistent application of learning expectations, learning objectives or learning standards. In instructional settings, rubrics clearly define academic expectations for students and help to ensure consistency in the evaluation of academic work from student to student, assignment to assignment, or course to course. Rubrics are also used as scoring instruments to determine grades or the degree to which learning standards have been demonstrated or attained by students.

After this we define and determine the evaluator agents, their role and which competences should be evaluated by everyone (phase 2). Evaluator agents are the responsible of following the students learning process. We have to determine the evaluation times along Internship course (phase 3) and built and design the partial evaluation reports (phase 4). With all information we can conclude the final mark of the student, joining the partial evaluation of the agents (phase 5). That mark will be the final qualification of the student but we add to it a final evaluation report detailed and personalized for every student which will contain every student' learning outcomes. This final report is unusual in public universities and we think could be a differentiation element from other institutions.

Future work will consist in testing this proposal in two groups of students of the degrees of Computer Engineering and Business Administration to evaluate and improve the model. Knowing it has to manage a lot of information it is need some computer support why otherwise the agents can be reticent to adopt and check the model.

\section{Results and Discussion}

First step, we split of the design of our rubric of evaluation (phase 1), which contains each all the competences fixed in the plan of studies of the corresponding degree. This rubric contents (see a summary of the rubric in table 1):

1. The definition of every competency

2. Its evidences

3. The moments of evaluation time

4. The agents who have to evaluate it.

This was the first step of the design of the integral process evaluation of Internship.

In this rubric is basic to have the description and clear detail of what understands /comprises in each one of the competency considered, because this will determine the different indicators/evidence of evaluation. To make this exercise is important to review studies like the Tejada (2005) and the one of De la Mano and Moro (2009), which help us to know the keys or fundamental contents that has to have a competency. As example, in the table 1 we show an item of the evaluation rubric of 
the Degree of Computer Science, where details the competency "Oral and written correction”, competency defined by the university of Lleida for all its degrees.

Table 1. Description and evidence of the competency: "Correction in the oral and written expression"

Competency UDL1: Correction in the oral and written expression

\section{Description}

Capacity to express with clarity and opportunity the ideas, knowledge and own feelings through the word, the writing and the graphic support, adapting to the characteristics of the situation and the audience.

Evidences of the competency (indicators that shows that the student has acquired the competency)

The student has to be able to answer to the following items:

a) Explains ideas and concepts of a comprehensible form.

b) Uses with precision form the technical vocabulary.

c) Uses the suitable vocabulary in each circumstance.

d) Uses of suitable form, the no verbal communication in the oral exhibition.

e) Relates properly the concepts along the speech.

f) Writes with linguistic correction.

g) Structures of coherent form the different sections of the documentation.

When we have defined every competency and the evidences linked to it we had to translate the theoretical model (rubric) to the reality of the classrooms and the companies (phase 2). In this point, is relevant to develop a new work with the main agents involved in the evaluation process, to identify and contrast what considers each one that has to or can be evaluate with the different competences. First of all we have to define the agents involved in the evaluation:

- Academic tutor: Person responsible in the School of Internship.

- Tutor of the company: Person responsible in the company of Internship.

- Tribunal of Internship: A tribunal formed by three academic tutors.

- Student: Responsible of his/herself process of assessment.

A same competency should be evaluated by different agents in different moments, and it is necessary to adapt the evidences under distinct criteria, as a way to collect the different perspectives or surroundings of evaluation. From the initial rubric we initiated a process of discussion and collected of suggestions of the different evaluator agents, with the object to obtain a realistic form and to contrast the indicators/moments of evaluation by competences of the Internship (phase 3). This point of previous discussion was basic and tried to take advantage of previous experiences/capabilities that several agents had, because all of them have participated in Internship as evaluators.

As a result of phases 2 and 3, we determine which competences will be evaluated for every agent and in which moment. (See table 2) 
Table 2. Assessment Matrix (without evidences), Evaluator agents and Evaluation moments for each competency.

\begin{tabular}{|c|c|c|c|c|c|c|}
\hline \multirow{3}{*}{ COMPETENCES/SKILLS } & \multicolumn{6}{|c|}{$\begin{array}{l}\text { MOMENTS/EVALUATOR } \\
\text { AGENTS }\end{array}$} \\
\hline & \multicolumn{2}{|c|}{ M I } & \multicolumn{2}{|c|}{ M II } & \multicolumn{2}{|c|}{ M III } \\
\hline & $\mathrm{S}$ & AT & $\mathrm{S}$ & AT & $\mathrm{TC}$ & $\mathrm{T}$ \\
\hline SOCIAL SKILLS AT WORK & $\mathbf{X}$ & $\mathbf{X}$ & & $\mathbf{X}$ & & \\
\hline COMP UDL1: Correction in written and oral expression & & & & $\mathbf{X}$ & & $\mathbf{X}$ \\
\hline $\begin{array}{l}\text { COMP EPS3: Capacity to gather and interpret data, in the context } \\
\text { of an area of study, with the aim to made value judgments on } \\
\text { subjects related to social, scientist and ethical topics }\end{array}$ & & & & $\mathbf{X}$ & $\mathbf{X}$ & $\mathbf{X}$ \\
\hline $\begin{array}{l}\text { COMP EPS7: Capacity to work in situations of fault of } \\
\text { information and/or under pressing. }\end{array}$ & $\mathbf{X}$ & $\mathbf{X}$ & & & & \\
\hline $\begin{array}{l}\text { COMP EPS9: Capacity of work in team, unidisciplinar and } \\
\text { multidisciplinary. }\end{array}$ & & & & & $\mathbf{X}$ & $\mathbf{X}$ \\
\hline \multirow[t]{2}{*}{$\begin{array}{l}\text { COMP EPS10: Capacity to integrate inside the structure of the } \\
\text { company. }\end{array}$} & & & $\mathbf{X}$ & & $\mathbf{X}$ & \\
\hline & & $\mathbf{X}$ & $\mathbf{X}$ & & $\mathrm{X}$ & \\
\hline
\end{tabular}

It is important to emphasize that one competency can be evaluated by two or more different agents. For example EPS12 is evaluated by the academic tutor and the tutor of the company (see table 3). Therefore, we have adapted the checklist of evidence to each agent and we have designed a different report for each evaluator agent (Phase 4).

Table 3. Item EPS12 of evaluation report of academic tutor and tutor of the company

EPS12: Motivation for quality and continuous improvement

\begin{tabular}{|l|l|}
\hline Evaluation report of academic tutor & $\begin{array}{l}\text { Evaluation report of tutor of the } \\
\text { company }\end{array}$ \\
\hline $\begin{array}{l}\text { Evidences: } \\
\text { - He/She is methodical and } \\
\text { systematic with the work and } \\
\text { deadlines }\end{array}$ & $\begin{array}{r}\text { Evidences: } \\
\text { - He/She is methodical and } \\
\text { systematic with the work and pays } \\
\text { He/She complies with the formal } \\
\text { requirements }\end{array}$ \\
$\begin{array}{l}\text { He/She is capable of applying } \\
\text { the technical knowledge he/she } \\
\text { has acquired }\end{array}$ & $\begin{array}{l}\text { He/She get involved to the work } \\
\text { and shows concern about the work }\end{array}$ \\
& $\begin{array}{l}\text { He/She acts with motivation for } \\
\text { quality and even proposes } \\
\text { improvements. }\end{array}$ \\
\hline
\end{tabular}

The following step in this phase is to propose transparent and comparable evaluation descriptors suitable to the indicators of evaluation. We want to put the student in the varying degrees of command of each competency and also facilitate his qualification.

We define four levels of command of the competency and, at the same time, link these with numerical marks (from 0 to 10 ) 
1. Very high: It would correspond with a numerical qualification between 9 and 10

2. High: It would correspond with a numerical qualification between 7 and 8

3. Basic: It would correspond with a numerical qualification between 5 and 6

4. No surpassed: It would correspond with an equal numerical qualification or under to 4.

Finally, we describe the meaning of the level of command for every evidence of every competency/agent/moment of evaluation.

See in the table 4 the different levels of command proposed for the evaluation of the competency EPS12: Motivation for quality and continuous improvement, evaluated by de Academic tutor.

Table 4. Example of indicators and levels of command for EPS12: Motivation for quality and continuous improvement. Report of academic tutor

\begin{tabular}{|c|c|c|c|c|}
\hline \multirow[b]{2}{*}{ Evidence } & \multicolumn{4}{|c|}{ Levels of command } \\
\hline & $\begin{array}{l}\text { Very High } \\
\text { (Mark: Between } \\
9 \text { to 10) } \\
\end{array}$ & $\begin{array}{c}\text { High } \\
\text { (Mark: Between } 7 \text { to } \\
\text { 8) }\end{array}$ & $\begin{array}{c}\text { Basic } \\
\text { (Mark: Between } 5 \text { to } \\
\text { 6) }\end{array}$ & $\begin{array}{l}\text { No surpassed } \\
\text { (Mark: Between } 9 \text { to } \\
\text { 10) }\end{array}$ \\
\hline $\begin{array}{l}\text { He/She is methodical and } \\
\text { systematic with the work and } \\
\text { deadlines } \\
\text { Mark: }\end{array}$ & $\begin{array}{l}\text { He/She does the } \\
\text { tasks with method, } \\
\text { tenacity and on } \\
\text { time. Usually is } \\
\text { organized and } \\
\text { takes care about } \\
\text { the presentation }\end{array}$ & $\begin{array}{l}\text { He/She does the tasks } \\
\text { with method, tenacity } \\
\text { and on time. Usually is } \\
\text { organized and takes } \\
\text { care about the } \\
\text { presentation with any } \\
\text { exception }\end{array}$ & $\begin{array}{l}\text { He/She does the tasks } \\
\text { with method, tenacity } \\
\text { but not on time. } \\
\text { Sometimes is } \\
\text { organized and takes } \\
\text { care about the } \\
\text { presentation }\end{array}$ & $\begin{array}{c}\text { He/She has trouble } \\
\text { doing the tasks with } \\
\text { method, tenacity and } \\
\text { on time. Usually is not } \\
\text { organized and doesn't } \\
\text { take care about the } \\
\text { presentation }\end{array}$ \\
\hline $\begin{array}{l}\text { He/She complies with the } \\
\text { formal requirements } \\
\text { Mark: }\end{array}$ & $\begin{array}{c}\text { He/she shows will } \\
\text { to do the assigned } \\
\text { tasks and makes } \\
\text { them with win }\end{array}$ & $\begin{array}{l}\text { He/she shows will to } \\
\text { do the assigned tasks } \\
\text { and makes them with } \\
\text { win but with some } \\
\text { exception }\end{array}$ & $\begin{array}{l}\text { He/she shows will to } \\
\text { do the assigned tasks } \\
\text { and makes them with } \\
\text { win but with a few } \\
\text { exceptions }\end{array}$ & $\begin{array}{l}\text { Only on rare occasions } \\
\text { He/she shows will to } \\
\text { do the assigned tasks } \\
\text { and makes them with } \\
\text { win }\end{array}$ \\
\hline $\begin{array}{l}\text { He/She is capable of applying } \\
\text { the technical knowledge that } \\
\text { he/she has acquired } \\
\text { Mark: }\end{array}$ & $\begin{array}{l}\text { He/she tries to do } \\
\text { the tasks applying } \\
\text { the technicians } \\
\text { learnt and even } \\
\text { proposes } \\
\text { alternative } \\
\text { solutions }\end{array}$ & $\begin{array}{l}\text { Often he/she tries to do } \\
\text { the tasks applying the } \\
\text { technicians learnt and } \\
\text { few times proposes } \\
\text { alternative solutions }\end{array}$ & $\begin{array}{c}\text { Often he/she tries to do } \\
\text { the tasks applying the } \\
\text { technicians learnt but } \\
\text { not proposes } \\
\text { alternative solutions }\end{array}$ & $\begin{array}{l}\text { Only few times he/she } \\
\text { does the tasks applying } \\
\text { the technicians learnt } \\
\text { and never proposes } \\
\text { alternative solutions }\end{array}$ \\
\hline
\end{tabular}

In this point, once defined each level of command for each evidence, adapted to every evaluator agent, we can elaborate all the reports (phase 4).

We have to say that reports have a standard format of rubric but really are subrubrics from the global rubric. In the evaluation process we define two types of reports: weekly Reports of Follow-up and Evaluation Reports. The Follow-up Reports are completed by the student, under the review of the tutor of the company, during the stay in the company. Instead, the five Evaluation Reports are made by the different agents at the end of the stay in the company of practices and when the period of Internship is finish (semester or quarter). In figure 1 we summarize the reports management. 


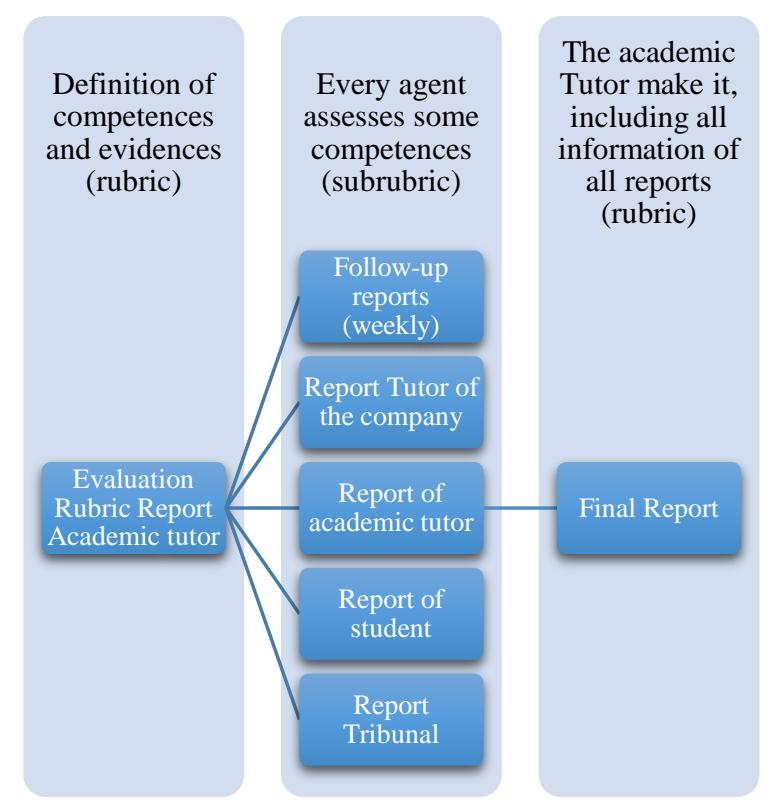

Figure 1. Summarize of reports management

Besides, each report of evaluation will have a specific weighting on the final qualification and the academic tutor has to join all information from all evaluation reports (Phase 5) and to calculate the final mark of student. The weight of the evaluation of every agent is:

- Evaluation report of the student: $10 \%$ of final mark

- Evaluation report of the tutor of the company: $30 \%$

- Evaluation report of the academic tutor: $40 \%$

- Evaluation report of the tribunal: $20 \%$

This model was tested by two groups of students of Internship along academic years 2012-2013 and 2013-2014 and our team had refined its design and ads, delete or redefine evidence. Different evaluator agents, students and companies have contributed to this process with suggestions that we incorporated in the rubric initially proposed.

Now, we are giving to the student a final qualification but without any detailed information about the level of acquirement of every competency, despite we have this information completed and structured. We thought that this information could be very significant because the competences of Internship are very useful to integrating students into the labour market. Therefore, we started to work in phase 5 of this project that consist in the design and definition of a final evaluation report, which include the final evaluation of every competency, of every agent, and final recommendations of the academic tutor.

This final report has to include:

1. GENERAL INFORMATION:

- The name of the student

- The name of the course

- The name of the Degree

- The name of School and University

- The year of the course 
- The name of the company where student did the internship

- The name of all evaluator agents

2. SPECIFIC INFORMATION:

- Every competency with every qualification of every agent (the whole rubric)

- The final qualification of every competency

- The final qualification of Internship

- Personalized recommendations of the academic tutor, who has being supervising the whole process of assessment.

However, given the high number of competences, evaluator agents, as well as, the students, it is crucial to have some software to automatize almost one part of this final report. This software should be integrated in our campus virtual based in Sakai and compatible with UdL information systems.

\section{Conclusions}

The redesign of the rubric of evaluation is the first result obtained from the implementation of our work during the 2 academic years 2012-13 and 2013-14. We have modified definitions and added some evidences with the aim to adapt the rubric to students and companies' needs and real situation in general.

Our proposal is able to have a final mark, combining complex information from all the evaluator agents in different time moments. As well as it guarantees that all the competences are evaluated at least by two agents. Our competency-based model shows learning outcomes and provide a clear set of expectations to students and companies. More over our proposal of final report allows students clearly to know about their level reached for every competency and some advice or comments from de academic tutor in order to improve their learning process.

This experience encourages our group to continue working in the Internship evaluation model with the final report.

\section{References}

Conde, A. \& Pozuelo, F.(2007). Las plantillas de evaluación (rúbrica) como instrumento para la evaluación. Un estudio de caso en el marco de la reforma de la enseñanza universitaria en el EEES. Investigación en la Escuela,63,77-90.

De La Mano González, M. \& Moro Cabero, M. (2009). La evaluación per competències: proposta d'un sistema de mesura per al grua d'Informació i Documentació. BiD. Textos universitaris de biblioteonomia i documentació, $n^{o}$ 23, desembre. Facultat de Biblioteconomia i Documentació Universitat de Barcelona.

Gallizo, J.L.; Badia, F.; Balcells, M.; Moltó, M.; Monyarc, J.; Motilva, MJ.; Ramos, A.; Tena, A. \& VendrelL, A. (2010). Adaptació específica del prácticum de la UdL en les noves titulacions de grau. VII Convocatòria d'ajuts per a Projectes d’Innovació Docent de la UdL.

Garcia, R. \& Puig, J (2011). A model for Improving the Quality of Student Internship Placements in Engineering Degrees. International Journal of Advanced Corporate Learning (iJAC), 2011, Vol.4(1), p4. 
KAN, A.(2007). An alternative method in the new educational program from the point of performance-based assessment. Rubric scoring scales, Educational Sciences: Theory \& Practice: 7 (1), 144152 (2007).

Moskal, B. M. \& Leydens, J. A. (2000): Scoring rubric development: validity and reliability. Practical Assessment, Research \& Evaluation, 7(10). Recuperado de http://pareonline.net/getvn.asp? $v=7 \& n=10$, Consultado el 12 de marzo de 2014

Tejada Fernández, J. (2005): El trabajo por competencias en el prácticum: cómo organizarlo y cómo evaluarlo. VIII Symposium Internacional sobre Prácticum y Prácticas en empresas en la formación universitaria, Poio, 30 junio-2 julio 2005.

Torres, J. J. \& Perera, V. H. (2010): La rúbrica como instrumento pedagógico para la tutorización y evaluación de los aprendizajes en el foro online en educación superior. Píxel-Bit. Revista de Medios y Educación, 36, 141-149 (2010) 